\title{
Semantic and pragmatic values of the Italian imperfetto: Towards a common interpretive procedure
}

\author{
Laura Baranzini ${ }^{1}$ \\ Claudia Ricci ${ }^{2}$ \\ Université de Neuchâtel \\ laura.baranzini@unine.ch \\ claudia.ricci@unine.ch
}

Received: May 19, 2015

Accepted: October 2, 2015

\begin{abstract}
This paper proposes an account of the semantics and pragmatics of the Italian indicative imperfect. This tense is described as deriving all of its uses from an extremely reduced core of semantic features as the point of departure to a series of interpretative paths leading to different contextrelated possible interpretations through a process of pragmatic enrichment. With regard to the temporal parameter, the semantics of the imperfect is described as conveying past temporal reference, with an underdetermined scope. With regard to the aspectual parameter, this tense is defined as not semantically determined at all. Upon pragmatic integration of contextual information, three main classes of meaning effects associated with the imperfect are assumed to emerge: a narrative effect, an evidential effect and an effect of activation of a preliminary phase in relation to the event. Based on the above mentioned features, an overall semantic-pragmatic mapping of the imperfect and of its interpretive procedure is proposed.
\end{abstract}

Keywords: imperfect; Italian; imperfetto; semantics; pragmatic enrichment; modal; evidential; past; reference; contextual interpretation; scope; change.

Resum. Valors semàntics i pragmàtics de l'imperfet italià: cap a un procediment interpretatiu comú

Aquest article dóna compte de la semàntica i la pragmàtica de l'imperfet italià. A la nostra descripció es mostra que aquest temps verbal deriva tots els seus usos d'un nucli extremadament reduït de trets semàntics, que són el punt de partida d'una sèrie de camins interpretatius que ens

1. This paper is part of a larger research project entitled Pragmatique procédurale cognitive du temps en italien (Cognitive procedural pragmatics of Tense in Italian, project n.100012_137967), directed by Louis de Saussure and financed by the Swiss National Science Foundation.

2. This paper is part of a larger research project entitled La représentation du sens modal et de ses tendances évolutives dans deux langues romanes: le français et l'italien (Representation of modal meaning and of the trends in its evolution in two Romance languages: French and Italian, project n.100012_159458), directed by Corinne Rossari and financed by the Swiss National Science Foundation. 
porten a diferents interpretacions possibles lligades al context mitjançant un procés d'enriquiment pragmàtic. Pel que fa al paràmetre temporal, mostrem que la semàntica de l'imperfet denota una referència temporal de passat d'abast indeterminat. Pel que fa al paràmetre aspectual, aquest temps no està semànticament definit en absolut. A partir de la integració pragmàtica de la informació contextual, apareixen tres classes principals d'efectes semàntics associats a l'imperfet: un efecte narratiu, un efecte evidencial i un efecte d'activació d'una fase anterior a l'esdeveniment denotat. Tot basant-nos en els trets esmentats, proposem una projecció de l'imperfet i del seu procediment interpretatiu des de la semàntica a la pragmàtica.

Paraules clau: imperfet; italià; imperfetto; semàntica; enriquiment pragmàtic; modal; evidencial; passat; referència; interpretació contextual; abast; canvi.

\section{Table of Contents}

\section{Introduction}

2. Temporal, aspectual and modal values of the imperfect in Italian

$$
\text { 3. A global taxonomy }
$$

4. The values of the Italian imperfetto: semantic features and pragmatic enrichment

5. Conclusions

References

\section{Introduction}

This paper aims at describing the semantics and pragmatics of the morphological form of the Italian indicative imperfect tense by illustrating at which level and along which parameters the process of enrichment of basic semantic features operates in terms of giving rise to the different possible interpretations of this form. Our starting hypothesis relies, therefore, on an eminently pragmatic perspective; we seek to derive all possible interpretations of the Italian imperfect tense from the contextual enrichment of a basic, limited core of semantic features. Such features potentially evolve in two directions. On the one hand, they acquire a specific sense via contextual integration towards a pragmatic interpretation. On the other hand, they also lead to a prototypical temporal-imperfective interpretation, which can emerge even when explicit contextual information is not available.

The first section $(\S 2)$ illustrates the various uses of the imperfetto as they are presented in the literature. This overview essentially takes into account the descriptions given in the literature on the Italian language - notably those by Bertinetto (1986, 1991), Bazzanella (1990), Serianni (1988), Squartini (2001), Mazzoleni (1992), Giacalone Ramat (1999), Lo Duca (1995), Ronconi (1944-45) and Nannoni (2004). The French imperfect has also been a highly debated topic in the last decade, giving rise to rich and fruitful discussion; we have thus chosen to also take into account some of the complex and detailed analyses provided for this typologically close language. Among the numerous contributions to the discussion, particular attention has been given to the works by Berthonneau and Kleiber (1993, 2006), Bres (2005, 2009), Saussure (2003), Saussure and Sthioul (1999, 2005), Patard (2007, 2010, 2014), Patard and De Mulder (2014), Vetters (1993, 2009), Wilmet $(1987,1996)$ and Touratier (1998). 
In a second step (§3), the uses of the imperfect tense will be included in a rational classification, making visible their characterizing features as well as their possible groupings. This will enable us to discuss some traditional categories while assessing the relevance of the descriptions given for some specific values of this tense.

In conclusion $(\S 4)$, we will propose an overall map of the process at play in the interpretation of the imperfect. Our schematization relies on a mechanism of enrichment, which draws on semantic features to obtain different interpretations depending on context-related conditions (for an in-depth discussion of our semantic characterization of the Italian imperfetto see Baranzini (to appear) and Baranzini and Ricci (in preparation)).

\section{Temporal, aspectual and modal values of the imperfect in Italian}

In this first section, we will attempt to provide as exhaustive as possible an account of the vast array of uses of the Italian imperfetto such as they are traditionally presented in grammars and research works on this tense. Describing such uses in detail (within a non-systematic approach) and illustrating them through a series of examples will enable us to have a closer look at their classification and at the relevant parameters.

\subsection{The prototypical tense of imperfectivity ${ }^{3}$}

Unanimously considered as the standard use of the imperfect, the imperfective temporal use is characterized by the association of two components: a temporal feature $[+$ past $]$ and an aspectual one [+imperfective $]^{4}$. According to the descriptions in the literature, choosing the imperfect allows the speaker to represent a state of affairs in the past from a particular aspectual perspective: the state of affairs is presented as having a certain duration and is not observed a posteriori (as is the case, for instance, when using the simple past tense); the event described by the verb is rather presented as in the process of taking place, from an 'internal' perspective, without visualizing its right boundary.

(1) Quando ero giovane ero molto ma molto povero, e naturalmente, come tutti i poveri, avevo degli ideali (A. Moravia, 1934, Milano, Bompiani, 1982) ${ }^{5}$

'When I was young I was very very poor, and naturally, like all poor people, I had ideals.'

3. See Baranzini (to appear) and Baranzini and Ricci (in preparation).

4. Serianni (1989: 468) states, "è un tipico tempo "aspettuale": segnala infatti un'azione incompiuta nel passato [...]; o meglio, un'azione passata le cui coordinate (momento d'inizio, conclusione, ecc.) restano inespresse." 'It is a typical 'aspectual' tense; it signals an action unaccomplished in the past $[. .$.$] or, better still, an action in the past whose coordinates (time of beginning, conclusion,$ etc.) remain unexpressed.'

5. Authentic examples are followed by an explicit indication of their source. In all the other cases, made-up examples have been preferred for the sake of clarity (especially when they had to be manipulated in view of a contrastive analysis). We are well aware of the limitations of this kind of choice, and our made-up examples have no other function than to illustrate a type of use based on the linguistic intuition of a native speaker. 
Choosing the imperfetto within the Italian past tense system allows visualizing the process from an internal point of view. The event is thus construed as being not punctual but durative. This standard use of the Italian imperfetto is involved in all the descriptions given in the literature, and it is most often taken as a starting point for the various attempts to explain all of its other uses. Such uses, however, do not necessarily follow the aspectual and temporal parameters described above. Our attempt to propose a scheme describing the semantic-pragmatic enrichment of the different uses of the Italian imperfetto will, therefore, lead us to reconsider either the definition of its temporal value or the assumption that this is the basic value within the description of its operational mechanism.

\subsection{Habitual value and continuous value}

In the accounts illustrating its 'standard' imperfective temporal uses, the Italian imperfetto is described as being able to convey three main aspectual values: progressive, habitual and continuous (see Bertinetto (1986)). Since they have been extensively defined and discussed in the literature, we will not provide a description of such values here. We limit ourselves to recalling the essential role of verbal aspectual class and contextual parameters in assigning one of the two values to the imperfect. Examples (2)-(4) ${ }^{6}$ illustrate respectively the progressive use, the habitual use and the continuous use of the imperfetto:

(2) Luigi dormiva placidamente nel suo letto, quando (all'improvviso) scoppiò un tuono formidabile.

'Luigi was sleeping [lit. Luigi sleep-IMPF] quietly in his bed, when (suddenly) thunder clapped loudly.'

(3) In quel periodo Pier Marco si alzava alle cinque.

'In that period, Pier Marco used to get up [lit. Pier Marco get-IMPF up] at five.'

(4) Per tutta la durata dell'incontro, Pier Marco guardava davanti a sé con aria desolata.

'During the whole meeting, Pier Marco kept looking before him [lit. Pier Marco look-IMPF before him] with a depressed look on his face.'

\subsection{The 'planning' use}

One of the parameters of variation involved in atypical uses of the Italian imperfect is indeed its temporal feature: the imperfetto - associated by definition with past temporal reference - appears to easily refer to an event located subsequently to the point of speech, as the following example shows:

6. Examples (2)-(4) are taken from Bertinetto (1986: 120, 140, 162). 
(5) Stasera andavamo a Roma; che fai, vieni? (ask.fm)

'We were going [lit. we GO-Impf] to Rome tonight; what about you? Are you going with us?'

In this case, the imperfect cannot be construed as locating the event in the past since co-text and context-related information undoubtedly convey a futural reading of the event in the utterance. We, therefore, need either to reconsider the status of the temporal feature of this tense (indeed, if a PAST-feature is part of the semantics of this tense, it cannot just be eradicated in interpreting these uses) or to rethink and redefine its temporal localization function within specific contexts, extending its scope.

\subsection{The narrative use}

The Italian imperfect may be used in a context in which the use of a perfective past tense would normally be required, either because the event described by the verb is viewed as completed or because the specific lexical aspect (Aktionsart) of the verb is more compatible with a perfective reading. In this case, the effect of the meaning of the imperfect is described as resulting from the visualization of the event from an internal perspective, which allows for focusing on the state of affairs in its course. ${ }^{7}$

(6) La mattina dopo, però, visto che la schiena non gli faceva più così male, Harrfey tirò fuori la sua Hillman Super Minx gonfio di aspettative. Due ore dopo entrava nel parcheggio riservato al campo $\mathrm{n}^{\circ} 1$, adiacente all'Old [sic] England Club. (Malcom Folley, Borg vs McEnroe, Monte Porzio Catone, Effepi, 2006 - original English text below)

'But the next morning, with his back no longer causing him discomfort, Harrfey moved his Hillman Super Minx out of his drive with a sense of anticipation. Two hours later, he pulled into No. 1 car park beside the All England Club.'

\subsection{The counterfactual use}

Counterfactual imperfect has been analyzed in depth in the literature on Italian (see in particular Mazzoleni (1992), Bazzanella (1990), Ronconi (1944-45)) and, mostly, on French (see for instance Bres (2009), Berthonneau and Kleiber (2006)). In contrast to competing past tenses, the imperfect is indeed typically described as capable of expressing an event that did not actually occur (not even in a fictional

7. A description of the mechanism of the narrative imperfect is provided by Ronconi (1943). The narrative use is presented as the result of the narrator's choice to give a static, durative representation of an event or of a specific part of it. As a result, the event is presented as being 'diluted' in time. According to Ronconi, this mechanism functions both in typically narrative uses (when the imperfect can be replaced with perfective tenses) and in descriptive, background uses of the tense. Bertinetto (1991) highlights the ambiguous nature of the imperfect in literary texts, showing for instance that it is often difficult to determine whether a 'narrative' (perfective) or a 'continuous' (imperfective) reading is more appropriate within a specific context. 
world). In these counterfactual uses, a state of affairs is evoked as possible while contextual indications require that it be interpreted as not having occurred:

(7) Incidente aereo, Capirossi illeso. "Ho avuto paura, sì, tanta paura. Altri trenta secondi e non c'ero più." (www.motograndprix.motorionline.com)

'Air crash, Capirossi unharmed. "I was scared, yes, really scared. Thirty more seconds and I would no longer have been here" [lit. I be-IMPF no longer here].'

Descriptions of this use of the imperfect tense often mention the fact that, in such a context, the imperfect can be replaced by a past conditional, a clear signal of the modality of unreality associated with the imperfect in this case. Here again, the analysis must focus on the articulation between the emergence of the counterfactual interpretation and the semantic core of this tense. The semantics of the imperfect allows, in effect, for a counterfactual reading, but such a reading is a purely pragmatic effect. This is shown by example (8) below in which the verb form used is the same as in (7) but the context requires that the event of 'no longer being there' is not construed as not having occurred:

(8) [Of a cake the speaker baked] È finita praticamente subito! Il tempo di metterla in tavola, cinque minuti e non c'era più. (blog.cookaround.com)

'It was gone practically instantly! Had just the time to put it on the table, five minutes, and it was no longer there.'

\subsection{The oneiric use}

Another 'modal' use of the Italian imperfetto is that of the account of a dream. This use is traditionally described as expressing a transition from the real world to irreality (see Bazzanella (1990)). In its oneiric value, the imperfect tense can be used regardless of the aspectual and prospective characterization of an event, and it can express the whole chain of events taking place in a narrated scene.

(9) Ero piccola, avevo sui tre o quattro anni, e uscivo a fare una passeggiata con mia madre. Ci fermavamo a parlare con una signora turca [...]. Nel sogno mia madre diceva qualcosa $[\ldots]$ che faceva arrabbiare la vecchia. Questa cominciava a urlare [...]. (M. Mustian, La memoria del vento, Milano, Piemme, 2011 - original English text below)

'I was very young, maybe three or four, out for a walk with my mother. We stopped and spoke to a Turkish woman [...].In the dream my mother said something $[\ldots]$ that made the old woman angry. She cried out $[\ldots]$.'

\subsection{The ludic use}

The expression 'ludic imperfect' covers uses of the imperfect limited to a specific type of discourse, namely that concerning the setting up and negotiating of scenarios in children's play. Developing and expressing a play context requires textual 
'theatrical staging' of a series of states and events, which can all be expressed by the imperfect tense. In such cases, variation from standard use concerns both the temporal and the aspectual plan. The states of affairs expressed by the imperfect describe both the ludic, fictional background itself - which can be referred to the past moment of its creation - and the future developments imagined for the situation; the temporal span expressed by the imperfect is, therefore, broad and heterogeneous. Moreover, the imperfect can here be used to express any type of aspectual value, be it an imperfective context or a clearly perfective one. This kind of 'temporal-aspectual elasticity' can be seen in the following example:

(10) Facciamo che tu eri in pericolo e io ti salvavo, sparavo al bandito, lo strozzavo e lo trasportavamo vicino al fiume... (C. Comencini, Matrioška, Milano, Feltrinelli, 2002)

'Let's pretend that you were in danger and I saved you, I shot the villain and strangled him, and we carried him close to the river...'

\subsection{Account of a fictional story}

The imperfect is used when narrating fictional events, typically in the form of a story (a book, a film, a play, etc.). Just as for the oneiric use, in this case, the imperfect can express all aspectual forms the processes can take:

(11) [...] sul secondo canale aveva visto questo film dove una donna, in seguito a una specie di maleficio, diventava prima sorda poi muta poi cieca e alla fine moriva. (F. Ramos, Diciotto ossa rotte, Milano, Baldini\&Castoldi, 2014) '[...] on the second channel she had watched this movie where a woman, because of a kind of bad spell, became first deaf, then dumb, then blind and in the end she died.'

\subsection{The mitigation use}

Finally, we will mention the so-called 'mitigation' or 'politeness' use of the imperfect, which conveys not past but present temporal reference:

(12) Salve le chiedevo se servite piatti a base di pesce e se siete aperti a pasqua. (tripadvisor.it)

'Hello. I wanted to ask [lit. I ask-IMPF] if you serve fish dishes and if you are open at Easter.'

This use is often accounted for (see for instance Ronconi (1944-45)) as an act of 'distancing' the situation of enunciation of a potentially threatening speech act by displacing it back to a past time; the fact of displacing the temporal reference of the utterance towards the past allows the speaker to mitigate the strength of his/her speech act (for instance, in the case of a request) or of his/her act of speaking out (for instance, in front of an audience or in another public context). 


\section{A global taxonomy}

The various uses of the imperfect have been grouped and classified in a number of ways, based on different criteria and leading to more or less organized and exhaustive taxonomies as a result. Even descriptions not specifically aiming at a classification tend to distinguish between so-called 'temporal' and 'modal' uses. These two uses are either treated as a non-related pair or as deriving from each other. In the latter case, the temporal uses are usually described as being the 'basic' uses; however, the imperfect has also been described as being inherently modal. ${ }^{8}$ If we opt for a definition of the two uses as being independent from each other, we must then assume the existence of a simple semantic core which can allow enrichment in both directions - towards a modal interpretation as well as a temporal one. ${ }^{9}$

We will now attempt to point out three parameters, which, in our view, are relevant when characterizing the uses of the imperfect tense:

i) we will consider uses in which the verb form can be associated with past temporal deixis and distinguish between the cases in which the past temporal reference is direct (the event is located in the past) and those in which it is indirect (the verbal morphology does not appear to apply to the event itself but to the decision-making or the conception of its realization);

ii) we will distinguish between a) uses in which the verbal morphology of the imperfect is inscribed in a tense-switching context, namely a context coherently alternating perfective forms and imperfect tense in which the imperfect is systematically construed as being imperfective, and b) uses in which the imperfect can autonomously convey the whole course of events in the discourse, making the presence of perfective tenses useless (tenses specialized in the expression of perfectivity are, in this case, only possible, sometimes even unacceptable); in such cases, the events expressed through the use of the imperfect can be contextually construed either as being imperfective or perfective. The morphological expression of aspectuality becomes somehow flattened;

iii) finally, we will distinguish between uses in which the imperfect refers to an event that actually occurred and uses in which the event did not - and will not, depending on the situation - occur. We will particularly focus our attention on this last distinction in an attempt to determine the circumstances where it is appropriate to talk about an event failing to occur. The process in question may not yet have occurred but may be due to occur in the future developments of events; in other cases, the event may not have occurred in the real situation, yet

8. Among the numerous proposals in this sense, we will mention, for French, the description in terms of subjectification and 'virtual reality' by De Mulder and Brisard (2006).

9. With regard to Italian, a unifying description of the possible values of the imperfetto is to be found in Ronconi (1944-45). Although his terminology sometimes differs from the one used in the current temporal-aspectual descriptions, two fundamental features are easily recognized as being, in the author's view, at the core of the semantics of this tense: its 'imperfective, i.e. continuous' nature ("imperfettiva, cioè continuata" Ronconi (1944-45: 64)) and what is described as the projection in the past of a present state of affairs. In this description, the context is presented as fundamental in determining the interpretation of the different uses. 
it is the object of an account where it has actually occurred in a fictitious, virtual world, evoked as experienced and relevant. Finally, the speaker might present the event as not having occurred while at the same time ruling out, a priori, any possibility of making relevant its realization as well as the consequences of this eventuality. This reflection will allow for a discussion of a characteristic of the imperfect tense which is apparently modal, namely its compatibility with the 'unreal' feature pertaining to a narrative context activated in discourse.

Table 1. Uses of the Italian imperfetto

\begin{tabular}{|c|c|c|c|}
\hline & $\begin{array}{l}\text { Realization of the } \\
\text { process }\end{array}$ & $\begin{array}{l}\text { Past temporal } \\
\text { reference }\end{array}$ & $\begin{array}{l}\text { 'Flattening' of the } \\
\text { aspectual use }\end{array}$ \\
\hline 'Standard' imperfect & $\begin{array}{l}\text { Presented as in } \\
\text { progress in the past }\end{array}$ & Direct & No \\
\hline Narrative imperfect & $\begin{array}{l}\text { Presented as having } \\
\text { occurred in a narrative } \\
\text { context }\end{array}$ & Direct & $\begin{array}{l}\text { Yes - as a subpart of a } \\
\text { whole }^{1}\end{array}$ \\
\hline 'Reporting' imperfect² & $\begin{array}{l}\text { Presented as having } \\
\text { occurred }\end{array}$ & Direct & Yes \\
\hline Mitigation imperfect & $?$ & $\begin{array}{l}\text { Indirect (decision } \\
\text { making or reason for } \\
\text { the process located in } \\
\text { the past) }\end{array}$ & Not relevant \\
\hline $\begin{array}{l}\text { 'Account of a fictional } \\
\text { story' imperfect }\end{array}$ & $\begin{array}{l}\text { Presented as having } \\
\text { occurred in a narrative } \\
\text { context }\end{array}$ & Direct & Yes \\
\hline Oneiric imperfect & $\begin{array}{l}\text { Presented as having } \\
\text { occurred in an oneiric } \\
\text { context }\end{array}$ & Direct & Yes \\
\hline Ludic imperfect & $\begin{array}{l}\text { Presented as not } \\
\text { having occurred; } \\
\text { realization in the } \\
\text { future in a role-playing } \\
\text { context }\end{array}$ & Indirect & Yes \\
\hline 'Planning' imperfect & $\begin{array}{l}\text { Presented as not } \\
\text { having occurred; the } \\
\text { possibility of realization } \\
\text { in the future is } \\
\text { admitted }\end{array}$ & $\begin{array}{l}\text { Indirect (decision- } \\
\text { making in the past) }\end{array}$ & Yes \\
\hline $\begin{array}{l}\text { Counterfactual } \\
\text { imperfect }\end{array}$ & $\begin{array}{l}\text { Presented as not } \\
\text { having occurred; the } \\
\text { possibility of realization } \\
\text { in the future is } \\
\text { excluded }\end{array}$ & $\begin{array}{l}\text { Indirect (evaluation of } \\
\text { the conditions for the } \\
\text { realization of the state } \\
\text { of affairs) }\end{array}$ & Yes \\
\hline
\end{tabular}

1. We believe it important to distinguish the narrative imperfect from the account of a fictional story precisely because the narrative imperfect characterizes a text portion including a succession of events but always within a broader narrative episode, which also includes perfective tenses. This amounts to describing the context in which a narrative imperfect can appear as a textual subpart of a whole.

2. We introduce this new category because this type of imperfect (described as typical of minutes or news articles) is very often associated with the category of the narrative imperfect, which we intend to treat separately here (see footnote 1 above). 
As shown in the table, the event itself can be directly situated in a moment located prior to the point of speech in two-thirds of the uses of the tense. The remaining three cases require the assumption that the verb form does not temporally locate the event itself but a relevant preparatory phase of the event - like, for instance, the decision-making process. By looking at this distribution of uses, we can assume the temporal feature to be indeed present in the semantics of the imperfect form but with an underspecified scope; under specific contextual conditions, a state of affairs preceding the event can be put under such a scope, excluding the event itself.

However, what is more significant (and, in our view, too often underestimated) about the imperfect is the fact that, among its different possible uses, the one which is traditionally considered 'standard' on an aspectual level is in fact relatively marginal. In all its other uses - which are numerous and diverse although probably less significant in frequency - the imperfect does not alternate with perfect tenses in a tenseswitching scheme but is used to express all aspectual nuances conveyed by a text. ${ }^{10}$

On the basis of these observations, in the next section, we will attempt to give an account of the different contextual variables allowing the emergence of one

10. Describing the imperfect tense on an aspectual level is a complex affair. This can be seen from the number of different treatments proposed and also from the cautiousness of knowledgeable, sensible scholars like Bertinetto (1986: 345). He initially describes the imperfect as "un tempo di natura nettamente imperfettiva" ('a tense positively imperfective in nature'). Subsequently (Bertinetto, 1986: 346), its definition seems less absolute ("Tempo fondamentalmente imperfettivo", 'fundamentally imperfective tense'). Finally (Bertinetto, 1986: 353), he states, "esistono validi motivi per asserire che l'uso dell'IPF è massimamente compatibile con contesti implicanti indeterminatezza. Abbiamo anche osservato, peraltro, che tale nozione non va intesa in senso brutalmente fattuale, perché il contesto (situazionale o linguistico) può sovente fornire precise informazioni, in merito allo svolgimento dell'evento. La conclusione generale che si impone è, dunque, che l'indeterminatezza non è unicamente sancita dall'insieme del messaggio testuale; essa è anche suggerita proprio dalla valenza imperfettiva in quanto tale, che può talvolta sopravanzare le contrastanti indicazioni contestuali" ('There are valid reasons on the basis of which it can be asserted that the use of the imperfect is mostly compatible with contexts implying indeterminacy. However, we have also observed that this notion must not be understood in a bluntly factual sense since the context (be it situational or linguistic) can often provide specific information concerning the way the event takes place. Therefore, it must be generally concluded that indeterminacy is not uniquely determined by the whole of the message conveyed by the text; it is also suggested precisely by the imperfective value as such, which can sometimes prevail over competing contextual indications'). Here is what Serianni (1989: 469) states about the narrative imperfect (also called the historical or 'newspaper' imperfect): "Il particolare valore di questo tempo verbale, che ha conosciuto una larga diffusione solo tra Otto e Novecento, parrebbe contravvenire alla "vocazione aspettuale" dell'imperfetto, in quanto assume spesso connotati decisamente perfettivi" ("the particular value of this tense, which was widespread only between the 19th and the 20th century, would appear to contravene the 'aspectual vocation' of the imperfect in that it often takes on clearly perfective features'). See also Grandi (2010) on a more general level: "sono generalmente associati all'aspetto imperfettivo la perifrasi progressiva e l'imperfetto; invece, il passato prossimo e il passato remoto paiono più prossimi all'aspetto perfettivo. Tuttavia va rammentato che, al di là di un evidente legame preferenziale tra alcuni tempi e alcune sfumature aspettuali, il contesto gioca un ruolo cruciale nell'interpretazione delle forme verbali" ('generally, to the imperfective aspect the literature associates the progressive periphrasis and the imperfect; [Italian] present perfect and simple past seem to be closer to perfective aspect. It should be remembered, however, that beyond a visible privileged link between specific tenses and specific aspectual nuances, the context has a crucial role in the interpretation of verb forms'). 
or the other reading of the imperfect, relying on the features that appear to bring together the largest number of uses.

Before moving on to the next section, however, let us look at the third parameter considered in our classification, namely, that concerning the actual realization of the process expressed by the verb.

On the one hand, there is obviously an interplay between the criterion concerning the realization of the process and that concerning temporal reference; while an event is expected to have occurred in the cases in which it is located in the past through direct temporal reference, the same does not hold true in the cases in which the past reference only concerns the decision-making process or a planning phase prior to the event and not the event itself.

On the other hand, a point worth deeper investigation is the fact that the imperfect appears to be preferably associated with contexts in which the situation is characterized as not being real. There is no doubt that the imperfect can be used to express both events which really occurred - or are in the process of occurring as is the case for the 'standard' imperfective reading - and the narration of imagined events with an alternation of imperfect and perfective past tenses. It is also evident, however, that, within specific contexts, the choice to narrate by only using the imperfect and the choice of alternating imperfect and perfective past tenses results in presenting the events from two very different 'modal' perspectives. We are speaking of the uses which we have referred to as an 'account of a fictional story' ${ }^{11}$, exemplified by (11) which we repeat under (13):

(13) $[\ldots]$ sul secondo canale aveva visto questo film dove una donna, in seguito a una specie di maleficio, diventava prima sorda poi muta poi cieca e alla fine moriva.

'[...] on the second channel she had watched this movie where a woman, because of a kind of bad spell, became [become-IMPF] first deaf, then dumb, then blind and in the end she died [die-IMPF].'

The cases considered here are characterized by the exclusive use of the imperfect for the narration. They, therefore, include partly what is called narrative imperfect, ${ }^{12}$ as well as the reporting 'newspaper' use, the 'account of a story' use, the oneiric use and the ludic use (see footnote 11). The core of our reflection is the following assumption. The narration entirely expressed through the use of the imperfect is, precisely as a result of the use of this tense, presented by the speaker as an account not mainly and exclusively of a series of events but also - or even more appropriately - as a mediated perceptive experience.

It is obvious that the characterization proposed here is not to be intended in terms of ontological adherence to reality, namely in terms of the real or unreal nature of the narrated events. Italian imperfetto di cronaca (reporting imperfect)

11. It is intuitively natural to also associate the oneiric and ludic account to this kind of narration.

12. While in the narrative use subparts of text are concerned, within such subparts, the neutralization of the distinction between a perfective and imperfective reading remains valid. 
is, for instance, prototypically associated with a medical report, with the process of drawing up the minutes of an interrogation by the police, or with the reporting of real facts by a journalist; a documentary reporting real facts can also be entirely recalled by using the imperfect. Our hypothesis does not concern an epistemic characterization of an event but the speaker's will to present his/her account together with his/her perceptual experience, thus signaling his/her enunciative distance from the events. Let us consider in this respect the different types of speaker exposure to the perception of events that are compatible with the type of accounts we are talking about:

i) The speaker may be reporting real events in which he/she has been actually involved

ii) The speaker may be reporting real events which he/she personally witnessed

iii) The speaker may be reporting real events that he/she got to know through the account of someone else within a spontaneous discourse context

iv) The speaker may be reporting real events that he/she got to know through the account of another speaker in a mediated, coded narrative context (witness report, minutes, news article)

v) The speaker may be reporting real events that he/she got to know through a narrative filter (audio-visual document, reading of a text)

vi) The speaker may be reporting unreal/imaginary events that he/she got to know through a narrative/imaginative filter (audio-visual document, reading of a text, an oneiric vision in a dream, the construction of an imaginary scenario, etc.)

With regard to cases mentioned in i), ii) and iii), a narration through the exclusive use of the imperfect hardly seems possible (see examples (15), (17) and (19) below). This is, however, not the case for iv) - in which the exclusive use of the imperfect is indeed a valid option - and for the most part for v) and vi) where the exclusive use of the imperfect appears to be virtually prototypical (see examples (22) and (24) below). If this hypothesis proves to be correct, ${ }^{13}$ the distinction between these uses could no longer be described as relying on the real or unreal nature of the narrated events. Rather, it should be defined in terms of the relevance of the activation of the speaker's cognitive experience; an account made using the imperfect form would reflect the choice of a speaker who has not integrated the narrated events into his/her own cognitive background and who would, therefore, signify his/her distance in terms of commitment through the use of a non-spontaneous, coded narrative filter. ${ }^{14}$ Following this line of reasoning would lead us to consider this feature as operating not on a purely modal level but rather on an evidential level

13. Since we do not have precise quantitative data on the presence/frequency of these configurations in Italian corpora, we must, obviously, speak in terms of hypotheses and intuitive assumptions.

14. In other words, according to this hypothesis, the imperfect is more compatible with a context in which the speaker explicitly presents him/herself as a 'communicative medium' for an account attributable to a third party. As for perfective tenses, they do not modify the epistemic status of the events; by the use of a perfective tense, the speaker presents himself/herself as a direct enunciative entity with all that this involves in terms of commitment. 
since this temporal-aspectual use ${ }^{15}$ would focus on an essential feature in relation to the source of information.

Evidence in this direction is visible when manipulating utterances through the variation of the above-mentioned parameters, which results in different degrees of acceptability (the following examples are instances of cases i) to vi) above:

i)

(14) Anni fa, in seguito a un grave incidente, sono diventata prima sorda poi cieca. ${ }^{16}$

'Years ago, due to a serious accident, I became first deaf, then blind.'

(15) ??Anni fa, in seguito a un grave incidente, diventavo prima sorda poi cieca. 'Years ago, due to a serious accident, I became [become-IMPF] first deaf, then blind.'

ii)

(16) Anni fa ho assistito a un terribile incidente. La ragazza coinvolta è diventata prima sorda poi cieca.

'Years ago, I witnessed a terrible accident. The girl involved became first deaf, then blind.'

(17) ??Anni fa ho assistito a un terribile incidente. La ragazza coinvolta diventava prima sorda poi cieca.

'Years ago, I witnessed a terrible accident. The girl involved became [becomeIMPF] first deaf, then blind.'

iii)

(18) Ieri la mia vicina mi ha raccontato un fatto spaventoso: tempo fa ha avuto un grave incidente ed è diventata prima sorda poi cieca.

'Yesterday, my neighbor told me about something terrible that happened: some time ago she had a very serious accident and became first deaf, then blind.'

(19) ?'Ieri la mia vicina mi ha raccontato un fatto spaventoso: tempo fa aveva un grave incidente e diventava prima sorda poi cieca.

'Yesterday, my neighbor told me about something terrible that happened: some time ago she had [have-IMPF] a very serious accident and became [become-IMPF] first deaf, then blind.'

15. While some lexical aspectual categories of verbs allow with greater probability for a 'perfective' reading of the imperfect, it should not be forgotten that such uses can only be defined on a textual level, i.e. within a global system.

16. The series of examples going from (14) to (28) has been obtained by manipulating the authentic example shown in (11) and (13). In the particular context of (11), contrary to what could be assumed, the presence of the imperfect in the relative clause is not determined by the presence of a past perfect tense in the governing clause. The simple past could here replace the past perfect within the same context, and the imperfect would still be grammatical. In order to illustrate the case under iv), a further authentic example has been added. 
iv)

(20) a. Si legge nel referto medico: "A seguito dell'incidente, la paziente diventava prima sorda, poi cieca".

'The medical report states: "Due to the accident, the patient became [become-IMPF] first deaf, then blind".'

b. Il giorno 26 gennaio 2013, in Roma, intervenuto unitamente ad un collega in occasione di un incendio divampato al primo piano di uno stabile, intuendo la gravità della situazione, senza attendere l'arrivo dei VV.F., abbatteva la porta d'ingresso ed ispezionava tutti i locali, rinvenendo una donna distesa su di un divano, priva di sensi. Portatala all'esterno in salvo, tornava nell'appartamento alla ricerca di altre persone. (http://www.fonda zionecarnegie.it)

'On January $26^{\text {th }}, 2013$, in Rome, having intervened with a colleague in the event of a fire which broke out on the first floor of a building, perceiving the gravity of the situation, without waiting for the firemen, [he] broke [break-IMPF] down the entrance door and inspected [inspect-IMPF] all premises, finding a woman lying on a couch, unconscious. Once he had rescued her by carrying her outside, he returned [return-IMPF] into the apartment looking for other persons.'

(21) a. Si legge nel referto medico: “A seguito dell'incidente, la paziente è diventata prima sorda, poi cieca".

'The medical report states: "Due to the accident, the patient became first deaf, then blind".'

b. Il giorno 26 gennaio 2013, in Roma, intervenuto unitamente ad un collega in occasione di un incendio divampato al primo piano di uno stabile, intuendo la gravità della situazione, senza attendere l'arrivo dei VV.F., ha abbattuto la porta d'ingresso ed ha ispezionato tutti i locali, rinvenendo una donna distesa su di un divano, priva di sensi. Portatala all'esterno in salvo, è tornato nell'appartamento alla ricerca di altre persone.

'On January $26^{\text {th }}, 2013$, in Rome, having intervened with a colleague in the event of a fire which broke out on the first floor of a building, perceiving the gravity of the situation, without waiting for the firemen, [he] broke down the entrance door and inspected all premises, finding a woman lying on a couch, unconscious. Once he had rescued her by carrying her outside, he returned into the apartment looking for other persons.'

v)

(22) [...] sul secondo canale aveva visto un documentario dove una donna, in seguito a un grave incidente, diventava prima sorda poi cieca.

'[...] on the second channel she had watched a documentary in which a woman, because of a serious accident, became [become-IMPF] first deaf, then blind.' 
(23)? ?...] sul secondo canale aveva visto un documentario dove una donna, in seguito a un grave incidente, è diventata prima sorda poi cieca. '[...] on the second channel she had watched a documentary in which a woman, because of a serious accident, became first deaf, then blind.'

vi)

(24) a. [...] sul secondo canale aveva visto questo film dove una donna, in seguito a una specie di maleficio, diventava prima sorda poi muta poi cieca e alla fine moriva.

'[...] on the second channel she had watched this movie where a woman, because of a kind of bad spell, became [become-IMPF] first deaf, then dumb, then blind and in the end she died [die-IMPF].'

b. Questa notte ho fatto uno strano sogno: in seguito a una specie di maleficio, diventavo prima sorda poi muta poi cieca e alla fine morivo.

'I had a strange dream last night: because of a kind of bad spell, I became [become-IMPF] first deaf, then dumb, then blind and in the end I died [die-IMPF].'

(25) a. ? ?... ] sul secondo canale aveva visto questo film dove una donna, in seguito a una specie di maleficio, è diventata prima sorda poi muta poi cieca e alla fine è morta.

'[...] on the second channel she had watched this movie where a woman, because of a kind of bad spell, became first deaf, then dumb, then blind and in the end she died.'

b. ?Questa notte ho fatto uno strano sogno: in seguito a una specie di maleficio, sono diventata prima sorda poi muta poi cieca e alla fine sono morta. 'I had a strange dream last night: because of a kind of bad spell, I became first deaf, then dumb, then blind and in the end I died.'

It is thus possible to rule out the ontological parameter as the one relevant for describing the alternation between the two temporal systems. However, the exact kind of 'evidential' characterization signaled by choosing the imperfect still has to be identified more precisely. It is not sufficient to describe it as a series of reported events in a narrative frame since a novel, the account of an event that the speaker has experienced first-hand, and an anecdote reported by another person may all be characterized as narrative texts, but they all allow for perfectly natural linguistic realization through the use of perfective tenses.

A significant hint about the nature of the evidential feature expressed through the choice of the imperfect in these contexts comes from an utterance such as (26) (previously (24a)): 
(26) [...] sul secondo canale aveva visto questo film dove una donna, in seguito a una specie di maleficio, diventava prima sorda poi muta poi cieca e alla fine moriva. '[...] on the second channel she had watched this movie where a woman, because of a kind of bad spell, became [become-IMPF] first deaf, then dumb, then blind and in the end she died [die-IMPF].'

As already observed, although not completely unacceptable, this account sounds less natural when a perfective tense is used (see (27), previously (25a)):

(27) ? [...] sul secondo canale aveva visto questo film dove una donna, in seguito a una specie di maleficio, è diventata prima sorda poi muta poi cieca e alla fine è morta.

'[...] on the second channel she had watched this movie where a woman, because of a kind of bad spell, became first deaf, then dumb, then blind and in the end she died.'

There is, though, one way that allows for restoring a more natural reading of this utterance: it is sufficient to insert it in a different narrative context, requiring the hearer to have watched the beginning of the movie together with the speaker so that he/she has direct knowledge of the protagonist of the story. This case is illustrated in (28):

(28) [Com'è finito il film di ieri sera? Io mi sono addormentato quasi subito...] E finito che la donna, in seguito a una specie di maleficio, è diventata prima sorda poi muta poi cieca e alla fine è morta.

'[How did yesterday's film end? I fell asleep right after the beginning...] In the end the woman, because of a kind of bad spell, became first deaf, then dumb, then blind and in the end she died.'

The result is not only perfectly acceptable, but also significantly more natural than what we would obtain by using the imperfect. In this case, two narrative filters are present (the vision of a fictitious story and the subsequent account by the speaker); as it appears, eliminating one of them amounts to adjusting the hearer's perception level - and consequently his/her knowledge background - to that of the speaker, which, in turn, makes the use of perfective tenses again an available, or even preferable, option.

In the light of these observations, it remains to be verified whether this commitment-based hypothesis is valid for all uses in which the account of a series of events can entirely be made using the imperfect tense.

\section{The values of the Italian imperfetto: semantic features and pragmatic enrichment}

On the basis of the observation in $\S 3$, we propose here an interpretative procedure for the Italian imperfect tense. Our point of departure is a significantly reduced 
semantic core; we then assign pragmatic enrichment a fundamental role in the process of interpretation. ${ }^{17}$ We consider that only one, underdetermined semantic feature can be associated with the imperfect form, this feature being past temporal reference. ${ }^{18}$ At this level, the scope of the imperfect is not specified. When no further contextual indications are available, what is located in the past is the event itself. When a specific context clearly does not allow for this kind of interpretation, the hearer must search for a preliminary, past situation related to the event - a planning or conception phase of it, for instance. In other words, what is located in the past is not the event but the moment of focalization of the event. According to Saussure (2003), for instance, in descriptive, temporal uses, the imperfect signals that the reference point $\mathrm{R}^{19}$ precedes $\mathrm{S}$ and that event $\mathrm{E}$ is true simultaneously with R, while nothing is said of E's truth conditions outside the boundaries of $\mathrm{R}$. What we propose here is in fact to associate the temporal information conveyed by the imperfect only with the moment of focalization valid at $R$ for all uses of the tense. Reference point $R$ is located in the past, but this is not necessarily the case for $\mathrm{E}$. What is visualized from $\mathrm{R}$ may be $\mathrm{E}$ or a moment of conception or imagination of $\mathrm{E}$. With respect to aspectuality, we consider all possible interpretations as deriving from the operation of pragmatic enrichment. ${ }^{20}$ The description proposed here differs in this respect from accounts which rely on an imperfective aspectual feature for the characterization of the semantics of the imperfect; it is in these terms, for instance, that Vetters (2009)

17. In this regard, our description is particularly close to that expressed in Saussure and Sthioul (2005: 104): “nous défendons l'idée d'une sous-détermination sémantique, estimant que c'est à travers la description du processus pragmatique lié à l'emploi d'une forme que les diverses valeurs peuvent être différenciées ('we defend the idea of a semantic underdetermination, as we believe that it is through the description of the pragmatic process involved in the use of a form that the various values can be differenciated'). Within the framework of Sperber and Wilson's Relevance Theory, the imperfect is here described as belonging to the category of procedural expressions, i.e. it encodes instructions on the interpretation of the utterance in which it appears. Its semantic description can be obtained by recurring to a number of underspecified semantic formulas containing variables, to which the hearer must assign a specific value (Saussure and Sthioul 2005: 105). The poverty of the semantic core of this verb form is thus a fundamental feature both in our description and in that of Saussure and Sthioul (2005).

18. It is worth being reminded that other attempts to resolve the tense-aspect and textual paradoxes related to the imperfect have been proposed. Molendijk (2002), for instance, describes the present perfect and simple past in French by reducing their characterization to a limited number of logic-temporal relations allowed by these two tenses in a sequence of utterances (which may be explicit or implicitly reconstructed). The semantics of the imperfect would, thus, be equivalent to a temporal relation of concomitance.

19. We follow here the traditional Reichenbach's notation $(\mathrm{R}=$ reference point, $\mathrm{S}=$ speech point, $\mathrm{E}=$ event point)

20. A similar description, characterizing the semantics of the imperfect tense as reduced to the presence of a 'past' feature with no further aspectual specification is proposed for French by Touratier (1998), although it concerns exclusively direct temporal uses of this tense. To account for the totality of its uses, the semantics of the imperfect is associated with a unique non-actual feature. However, this feature seems to be closer to the area of modality that to that of aspectuality. A notion of non-actual feature associated with the imperfect is commonly found in the literature. However, such a notion does not seem to coincide with our idea of purely aspectual underdetermination. 
describes the French imparfait, relying on pragmatic enrichment exclusively for perfective readings of the tense. In his view, perfective interpretation is obtained through the integration of contextual information, leading to the conclusion that the process expressed by the verb actually has been completed in a subsequent moment. ${ }^{21}$ As pointed out in Baranzini (to appear) and Baranzini and Ricci (in preparation), this kind of description of the meaning of the imperfect tense is not easily applicable in the case of Italian.

Below is a possible schematization of the different interpretative pathways associated with the imperfect in Italian:

Italian imperfetto: basic semantics

Past temporal reference with an underdetermined scope

(the scope is a moment of focalization simultaneous to the event)

When no specific contextual indications are given:

default interpretation $\rightarrow$ imperfective value: the moment of observation of the event is simultaneous to a moment internal to the course of the event.

Alternatively:

1. Presence of contextual indications $\rightarrow$ neutralization of the alternation between the imperfect and perfective tenses within a broader narrative context including imperfect-perfective tense alternation $\rightarrow$ narrative interpretation. Effect of meaning: static visualization of the ending phase of a narrative sequence. ${ }^{22}$

2. Presence of contextual indications $\rightarrow$ neutralization of the alternation between the imperfect and perfective tenses in the whole narrative sequence $\rightarrow$ evidential interpretation. Effect of meaning: 'enunciative distancing' (non-commitment) on the part of the speaker. ${ }^{23}$

21. A similar stance, based on contextual enrichment of the imperfect, which is described as always being imperfective, is adopted and thoroughly argued for French in Bres (2005), as well as in Caudal and Vetters (2005) and in Labeau (2005).

22. The closing effect of the narrative imperfect appears to be intuitive, as shown for example in the academic online coursebook by Kaempfer and Micheli (2005).

23. We are reminded here that a modal value of epistemic distancing has already been associated with the imperfect (see Patard and De Mulder (2014)), although it only concerns its hypothetical uses, not narrative effects. In De Mulder and Brisard (2006), the epistemic feature is systematically associated with the imperfect tense; the authors introduce the notion of a 'centre de conceptualisation' (centre of conceptualization), which appears to be close to the 'sujet d'observation' (subject of observation) described in Saussure and Sthioul (2005). An evidential characterization of a specific type of Italian modal imperfect is provided by Squartini (2001). The analysis is focused on the use of the imperfect, which we have referred to as a 'planning' or 'futural' use. This use is described as evidential in that it involves the 'evidential mode of knowing' (Squartini (2001: 309)) of the speaker, who reports, through the use of the imperfect, his/her past knowledge about an event as being due to happen, with no direct confirmation or knowledge about the actual occurrence of the planned event. Berretta (1992) explains some of these 'planning' uses by assigning the imperfect the property of being inherently non-factual. 
3. Presence of contextual indications $\rightarrow$ the scope of temporal reference is not compatible with the state of affairs expressed by the verb $\rightarrow$ interpretation: the temporal reference has in its scope a preliminary (past) phase related to the event. The event expressed by the verb is presented as not having occurred.

$\longrightarrow$ Context: the event is planned and due to take place in the future; its realization is presented as being more or less subject to possible cancellation $\rightarrow$ effect of meaning: factual or open planning

$\rightarrow$ Context: the realization of the event is excluded in a past, present or future time $\rightarrow$ effect of meaning: counterfactuality

$\rightarrow$ Context: specific lexical context; the event is valid at the point of speech; justifying one's illocutionary act seems relevant $\rightarrow$ effect of meaning: mitigation

This scheme may be read in the following terms; the imperfect characterizes an event $E$ or a moment/phase in time associated with $E$ preceding $S$.

The default interpretation (when no further contextual indications are given or when perfective tenses are present) can be expressed as follows. In terms of aspectuality, the imperfect is imperfective; the moment of observation of the event is simultaneous to a moment which is internal to the course of the event. ${ }^{24}$

The basic semantic value of the imperfect can be contextually enriched in different ways, leading to a number of possible interpretations, which we have grouped as follows:

Contextual indications: neutralization of the alternation between the imperfect and perfective tenses in a limited subpart of a broader narrative context including imperfect-perfective tense alternation

i) Within a context where perfective tenses and the imperfect alternate, the narrative sequence may present a limited sequence of utterances where the imperfect is used for the expression of globally perfective situations. In such cases, a narrative type of interpretation is reconstructed. The effect of meaning obtained is a global static visualization of a group of events, which stems from narrative tension..$^{25}$

Contextual indications: neutralization of the alternation between the imperfect and perfective tenses

ii) When specific contextual information allows it, the alternation between the imperfect - traditionally seen as a narrative 'background' tense - and perfective

24. As already mentioned, we will not discuss here the distinction between the progressive aspect, habitual aspect and continuous aspect.

25. In our view, the narrative use is the most difficult to account for within a coherent, unified description. Although it shares some of its features with other 'perfective' uses of the imperfect, it differs significantly from them on other levels. It should be added that it is, in most cases, very difficult when not impossible - to find contexts totally ruling out the possibility of using a specific tense. As a result, intuitions concerning effects of meaning related to the choice of one or the other solution seem particularly blurred. 
tenses - described as signaling narrative progression of events - may be neutralized within a whole narrative sequence. The imperfect can here be used both imperfectively and perfectively, and it can cover all the phases of the narrative sequence, replacing perfective tenses. Each event is visualized as being a whole and, consequently, as marking narrative progression. In such cases, pragmatic enrichment leads to an evidential interpretation, involving the notion of commitment on the part of the speaker. The uses concerned here are the oneiric use, the ludic use ${ }^{26}$ and the imperfect used to give an account of fictional stories (like books or films), as well as what we called the 'reporting' use (news, minutes).

In all such cases, past reference concerns not only the event itself but also the moment in which the speaker is exposed to the narrative experience of the event (dream, ludic scenario planning, reading a book, watching a movie, listening to a testimony); the speaker presents the events as not being part of his/her background knowledge. The prototypical tenses for these kinds of contexts are, thus, the imperfect or the present tense while the choice of a perfective tense appears to be less appropriate.

The characterizing element of these uses appears, therefore, as being of an evidential nature; the speaker does not integrate the state of affairs on a cognitive level, and, consequently, does not endorse this state on a commitment level. On the contrary, perfective tenses allow presenting content as entirely under the scope of the speaker's commitment.

\section{Contextual indications: the event expressed by the verb is not directly under the scope of the past temporal reference conveyed by the imperfect tense}

iii) The interpretation in which the temporal feature conveyed by the imperfect refers directly to the event expressed by the verb may be blocked by specific contextual indications. We refer here to cases in which temporal past reference can by no means be construed as having the event itself under its scope (the event must be interpreted as not having occurred); the hearer must, therefore, search for a relevant preliminary moment or phase related to the event. Typically, this phase concerns the event conception, its planning or the decision-making process related to it. ${ }^{27}$

Specific contextual indications suggest various ways in which different circumstances leading to the possible non-realization of an event may emerge. The resulting effects of meaning can be grouped as follows:

1. Interpretation in terms of factual or 'open' planning. When no contextual indication suggests that the speaker may act to modify the course of events, the planning phase of the event is focalized and the event is interpreted as programmed:

26. We are aware of the fact that the ludic use of the imperfect seems to exploit both types of possible mechanisms involved in the use of this tense; therefore, if stress had to be put on the imperfect's property to focus on a preceding phase of the event, the ludic use could also be classified within group 3, as a specific type of planning imperfect.

27. Bazzanella (1990) accounts for modal uses of the imperfect in terms of this tense's property of being able to convey the distance along the axis realis/irrealis through pragmatic exploitation of its temporal feature. 
(29) Non comprare la bistecca per cena, oggi Amelia all'asilo mangiava la carne 'Don't buy steak for dinner, Amelia is having [lit: eat-IMPF] meat at kindergarten today' (real utterance, 9 a.m.)

If it is contextually made relevant that the speaker might modify the course of events, the planning phase of the event is focalized and the event is construed as being the result of decision making, while at the same time taking into account the possibility that the event itself might not occur. This is envisaged to different extents, going from mere possibility to actual non-realization and, thus, to counterfactuality. ${ }^{28}$

(30) bond tu vai mai a sandonnino? io quasi quasi stasera facevo una capatina super veloce (da mandy) (escortforum.it)

'Bond, do you ever go to Sandonnino? I've half a mind to quickly stop by [lit. I stop-IMPF by] tonight (at Mandy's place).'

\section{Interpretation in terms of counterfactuality. Some contexts lead to interpreting} the realization of the event expressed by the verb as subject to specific conditions. The past temporal feature refers, in this case, to the time in which these conditions could have been fulfilled. ${ }^{29}$ The situation referred to, however, does not hold true at the moment of utterance; through pragmatic enrichment, the event is, thus, construed not only as not having occurred but also as not liable to occur. ${ }^{30}$

28. Bazzanella (1990) and Mazzoleni (1992) talk about an interaction which is still negotiable.

29. It is worth being reminded that the conditions made explicit in the utterance are positive conditions, meaning the conditions under which the event expressed through the imperfect could have taken place and not the negative state of affairs (the missed occurrence of the event) being experienced in reality.

30. Berthonneau and Kleiber (2006) provide a detailed description of the mechanism at the core of the counterfactual value of the imperfect. This value is described as obtainable through specific contextual information and the presence of a specific structure consisting of two elements: the imperfect tense and a 'front complement' (like, for instance, 'one minute more', 'two kilograms less'); in these cases, the imperfect presents the event as part of a global situation, which the co-text or the context has made relevant. The front complement is responsible for modifying a part or a property pertaining to this situation in a quantitative way or by adding/subtracting an element. This, combined with the speaker's knowledge that the situation is already closed, leads to the conclusion that the modification operated by the front complement has actually not occurred (in the case of 'two minutes more, and I miss-IMPF the train', for instance, the 'two minutes more' did not, in effect, occur). Consequently, the event described by the verb is also envisaged as not having occurred either. The possibility for the imperfect to convey counterfactuality (in contrast to perfective tenses) is thus accounted for in terms of the event being part of a situation in combination with its anaphoric nature. Patard and De Mulder (2014) explain the fact that, already in Latin, the imperfect replaced the subjunctive in unreal hypothetical constructions through its purely temporal feature (an aspectual feature is also envisaged with some verbs). In their view, the hypothetical contexts, characterized as modal, allowed for a transition towards a modal meaning associated directly with the imperfect in a path towards a complete dissociation from past temporality in Late Latin and Ancient French. 
(31) Monti: senza le mie scelte impopolari, andavamo a sbattere. (www.fanpage.it) 'Monti: without my unpopular choices, we would have crashed [lit. we crashIMPF].'

(32) Incidente aereo, Capirossi illeso. "Ho avuto paura, sì, tanta paura. Altri 30 secondi e non c'ero più".

'Air crash, Capirossi unharmed. "I was scared, yes, really scared. Thirty more seconds and I would no longer have been here [lit. I be-IMPF no longer here]".

(33) Finalmente la WTA ha capito di cambiare la programmazione. Altrimenti domani giocava la Allister al posto della Sharapova. (Internet)

'At last, WTA understood they had to change their planning. Otherwise, tomorrow, Allister would have played [lit. Allister play-IMPF] instead of Sharapova.'

3. Interpretation in terms of mitigation. In some cases, the context can make relevant a situation in which the actual occurrence of a state of affairs is presented as only imagined or decided but not yet accomplished. In fact, the realization of the event is to be located in the present discourse situation; however, the speaker chooses, through the use of the imperfect, to focalize attention on the preceding decisional phase. The effect of such a choice appears to be the following. The speaker may want to inform the hearer that his/her planning of an event in the past does not necessarily entail its actual realization, which is, in any case, subject to the hearer's approval. This holds particularly true for acts of request, for which it is seen as socially more acceptable to fictionally leave it up to the hearer to block the illocutionary act before it is effective. Moreover, activating a prior decisionmaking phase allows the speaker to further justify or explain the illocutionary act, which is potentially face threatening, by communicating that it had been decided, desired or needed in the past.

While this kind of effect of meaning allows explaining a number of mitigation uses (which are rather limited and stereotyped in their lexical manifestation), it is also true that this same kind of imperfect can be used in contexts that do not necessarily display such a 'social' management of a request:

(34) [Fra amici] Ah, senti, volevo dirti una cosa a questo proposito. ${ }^{31}$ '[Among friends] Oh, yes, listen, I wanted to tell you something about that.'

(35) Pensavo che potevamo preparare una torta, oggi.

'I thought we might bake a cake today.'

31. In contexts conveying structures modalizing the action, like modal auxiliaries or similar constructions (to want, to wish, to ask, etc.) the future occurring of the event is construed as being somewhat 'open'. This allows us to bring together the mitigation use and the planning use. 
In this kind of utterance, the imperfect appears to be functioning in a slightly different way. By activating a time prior to the speech point, the speaker simply means to signal that the illocutionary act has been conceived before; thus, excluding it may be the effect of contingent circumstances.

In these types of cases, therefore, the pragmatic enrichment stops at a previous stage, a stage, which is also necessary - though not sufficient - for the interpretation of the first category of the attenuation imperfect considered above. This is shown in (37) by a client's answer to the grocer:

(36) A: Cosa desidera, signora? B: Volevo due etti di prosciutto.

'A: What would you like, Madam? B: I wanted 200 gr. of ham.'

(37) A: Cosa desidera, signora? B: ??Aspetti, non ho ancora deciso. Ma sì, volevo due etti di prosciutto.

'A: What would you like, Madam? B: Just a moment. I haven't made up my mind yet. OK then, I wanted 200 gr. of ham.'

In contrast, as an answer to the question in (36), (38) or (39) are both perfectly natural:

(38) A: Cosa desidera, signora? B: Aspetti, non ho ancora deciso. Ma sì, voglio due etti di prosciutto.

'A: What would you like, Madam? B: Just a moment. I haven't made up my mind yet. OK then, I want 200 gr. of ham.'

(39) A: Cosa desidera, signora? B: Aspetti, non ricordo. Ah sì, volevo due etti di prosciutto.

'A: What would you like, Madam? B: Just a moment. I can't remember right now. Oh, yes, that's it, I wanted 200 gr. of ham.'

The routinization of this kind of illocution with the imperfect might allow some margin for expansion towards contexts in which the activation of a mitigating mechanism seems less relevant, yet the speaker feels the will to present his/her act as the result of retrieving an idea conceived in the past.

\section{Conclusions}

In this paper, we have attempted to propose an interpretative procedure of the Italian imperfect tense. To this end, we have relied on common semantic features to articulate a series of different interpretative paths leading to each of the different contextrelated possible interpretations of this tense. In conclusion, let us summarize the hypotheses that differ - partially or totally - from the traditional description of this verb form. With regard to the temporal parameter, we have assigned the imperfect a past temporal reference function with a scope either on the event itself or on a planning phase of the event. With regard to the aspectual parameter, we have defined the 
imperfect as not semantically determined. The grounds for this assumption have not been discussed in depth for reasons of space. Finally, we have associated an effect of meaning in terms of evidentiality to one subgroup of uses of the imperfect while another subgroup has been characteristically associated with an effect of the 'activation of a moment of consciousness related to the event' (on the basis of the semantic necessity to resume a past temporal reference), occurring in a time in which the event itself is not presented as having taken place, with various possible declinations in terms of interpretation. Far from being complete, our investigation still requires further development in many directions. While our research on the aspectual status of this tense is already in progress, further investigation areas are the description of the different effects of the meaning and textual effects of the narrative imperfect and the discussion on the evidential hypothesis proposed for reporting uses, as well as a general French-Italian contrastive analysis of this verb form.

\section{References}

Baranzini, Laura (to appear). Imparfait et imperfectivité en italien. Syntaxe et sémantique 17.

Baranzini, Laura; Ricci, Claudia (in preparation). The meaning of the Italian indicativo imperfetto: aspectual imperfectivity and other semantic-pragmatic issues.

Bazzanella, Carla (1990). "Modal uses of the Italian Indicativo imperfetto in a pragmatic perspective". Journal of pragmatics 14,3: 237-255. $<\mathrm{http} / / / \mathrm{dx}$. doi.org/10.1016/0378-2166(90)90100-R>

Berretta, Monica (1992). "Sul sistema di tempo, aspetto e modo nell'italiano contemporaneo". In: Moretti, Bruno; Petrini, Dario; Bianconi, Sandro (eds). Linee di tendenza dell'italiano contemporaneo. Roma: Bulzoni, pp. 135-153.

Bertinetto, Pier Marco (1986). Tempo, aspetto e azione nel verbo italiano. Il sistema dell'indicativo. Firenze: Accademia della Crusca.

Bertinetto, Pier Marco (1991). "Il verbo". In: Renzi, Lorenzo; Salvi, Giampaolo; Cardinaletti, Anna (eds). Grande grammatica italiana di consultazione. Bologna: il Mulino, vol. $2^{\circ}$ ("I sintagmi verbale, aggettivale, avverbiale. La subordinazione"), pp. 13-161.

Berthonneau Anne-Marie; Kleiber, Georges (1993). "Pour une nouvelle approche de l'imparfait: L'imparfait, un temps anaphorique méronomique". In: Moeschler, Jacques (ed). Temps, référence et inférence. Langages 112: 55-73.

Berthonneau Anne-Marie; Kleiber, Georges (2006). "Sur l'imparfait contrefactuel". Travaux de linguistique 53: 7-65. $<\mathrm{http}: / / \mathrm{dx}$.doi.org/10.3917/t1.053.0007>

Bres, Jacques (2005). "L'imparfait : l'un et/ou le multiple ? A propos des imparfaits « narratif » et « d'hypothèse »". In: Labeau Emmanuelle and Larrivée Pierre (eds.). Nouveaux développements de l'imparfait, Amsterdam/New York: Rodopi, pp. 1-32.

Bres, Jacques (2009). "Sans l'imparfait, les vendanges tardives ne rentraient pas dans la jupe rhénane... Sur l'imparfait contrefactuel, pour avancer". Syntaxe et sémantique 10: 33-50.

Caudal, Patrick. and Vetters, Carl (2005). “Que l'imparfait n'est pas (encore) un prétérit". In: Labeau Emmanuelle and Larrivée Pierre (eds.). Nouveaux développements de l'imparfait, Amsterdam/New York: Rodopi, pp. 45-77. 
Giacalone Ramat, Anna (1999). "Grammaticalization of modality in language acquisition”. Studies in language 23: 377-407. $<$ http://dx.doi.org/10.1075/s1.23.2.06gia >

Grandi, Nicola (2010). “Aspetto”. In: Enciclopedia dell'italiano. Web portal treccani.it. Labeau Emmanuelle and Larrivée Pierre (eds.) (2005). Nouveaux développements de l'imparfait, Amsterdam / New York: Rodopi.

Lo Duca, Maria Giuseppina (1995). 'Imperfetto ‘ludico' e altri tempi: una prospettiva testuale”. In: Giacalone Ramat, Anna and Crocco Galèas, Grazia (eds.). From Pragmatics to Syntax: Modality in Second Language Acquisition. Tubingen: Narr, pp. 173-194.

Mazzoleni, Marco (1992). “'Se lo sapevo non ci venivo': l'imperfetto indicativo ipotetico nell'italiano contemporaneo". In: Moretti, Bruno; Petrini, Dario; Bianconi, Sandro (eds). Linee di tendenza dell'italiano contemporaneo. Roma: Bulzoni, pp. 171-189.

Molendijk, Arie L. (1987). "Point référentiel et implication temporelle: le passé simple et l'imparfait du français". In: Kampers-Manhe, Brigitte; Vet, Co (eds.). Études de linguistique française offertes à Robert de Dardel par ses amis et collègues. Amsterdam: Rodopi, pp. 109-126.

Molendijk, Arie L. (2002). "La structuration logico-temporelle du texte : le passé simple et l'imparfait du français". In: Labeau, Emmanuelle; Larrivée, Pierre. Les temps du passé français et leur enseignement. Amsterdam/New York: Rodopi, pp. 91-104.

Nannoni, Catia (2004). L'imperfetto tra linguistica e traduzione. Trieste: Università degli Studi di Trieste.

Patard, Adeline (2007). L'un et le multiple. L'imparfait de l'indicatif en français : valeur en langue et usage en discours. Montpellier: Université Paul-Valéry.

Patard, Adeline (2010). “L'emploi préludique de l'imparfait entre temporalité et modalité : Éléments d'analyse à partir d'une étude de cas". Journal of French Language Studies 20.2: 189-211. $<$ http://dx.doi.org/10.1017/S0959269509990494>

Patard, Adeline (2014). "When tense and aspect convey modality. Reflections on the modal uses of past tenses in Romance and Germanic languages". Journal of pragmatics 71: 69-97.

$<$ http://dx.doi.org/10.1016/j.pragma.2014.06.009>

Patard, Adeline and De Mulder, Walter (2014). "Aux origines des emplois modaux de l'imparfait . Le cas de l'emploi hypothétique et de l'emploi contrefactuel". Langages 193: 33-47.

$<$ http://dx.doi.org/10.3917/lang.193.0033>

Ronconi, Alessandro (1943). “L’imperfetto descrittivo”. Lingua Nostra 5: 90-93.

Ronconi, Alessandro (1944-45). "L'imperfetto di modestia e l'imperfetto 'irreale". Lingua nostra 6: 64-66.

Saussure, Louis de (2003). Temps et pertinence, Bruxelles: Duculot /de Boeck.

Saussure, Louis de and Sthioul, Bertrand (1999). "L'imparfait narratif: point de vue (et images du monde)". Cahiers de praxématique 32: 167-188.

Saussure, Louis de and Sthioul, Bertrand (2005). "Imparfait et enrichissement pragmatique". In: Labeau, Emmanuelle and Larrivée, Pierre (eds.). Nouveaux développements de l'imparfait. Amsterdam/New York: Rodopi, pp. 103-120.

Serianni, Luca (1989). Grammatica italiana (with Alberto Castelvecchi). Torino: UTET. 
Squartini, Mario (2001). “The internal structure of evidentiality in Romance”. Studies in Language 25,2: 297-334. $<$ http://dx.doi.org/10.1075/s1.25.2.05squ>

Tasmowski-De Ryck, Liliane (1985). "L'imparfait avec et sans rupture”. Langue française 67: 59-77. $<$ http://dx.doi.org/10.3406/lfr.1985.4651>

Touratier, Christian (1998). "L’imparfait. Temps du passé non marqué”. Cahiers Chronos 2: 21-28.

Valuet, Maurice (1991). "Note sur l'imparfait en fonction du passé simple". Moderne Sprachen 35, 2: 55-56.

Vetters, Carl (1993). "Passé simple et imparfait: un couple mal assorti". Langue française 100: 14-30. $<$ http://dx.doi.org/10.3406/lfr.1993.5924>

Vetters, Carl (2009). “L'interaction entre sémantique et pragmatique dans l'interprétation des temps du passé en français". In: Verbeken, Dominique (ed.). Entre sens et signification. Paris: L'Harmattan, pp. 11-25.

Wilmet, Marc (1987). “L'éternel imparfait”. Modèles linguistiques IX, 2:169-177.

Wilmet, Marc (1996). “L'imparfait: le temps des anaphores?". Cahiers Chronos 1: 199-215. 